\section{BESTATIN, AN INHIBITOR OF AMINOPEPTIDASE B, PRODUCED BY ACTINOMYCETES}

Sir :

As we reported previously ${ }^{1-8)}$, inhibitors of such endopeptidases as trypsin, plasmin, papain, chymotrypsin, elastase, acid protease and thermolysin have been found in culture filtrates of actinomycetes. Recently we found that exopeptidases have a strong effect on mammalian cell surfaces compared to endopeptidases ${ }^{9)}$. It is possible that the action of hydrolytic enzymes on cell surfaces is involved in various cellular phenomena. We thought that exopeptidase inhibitors would be useful in the analysis of biological functions. So, we started screening of actinomycetes culture filtrates for activity against aminopeptidase B, and found a new compound bestatin, the discovery and isolation of which are reported herein.

As described by Hopsu et al. ${ }^{10)}$, aminopeptidase B (EC 3.4.11.6) is an exopeptidase which can be obtained from rat liver. It hydrolyses an N-terminal peptide bond containing $\mathrm{N}$-terminal arginine or lysine. In order to obtain quantitative values for antiaminopeptidase B activity, we established the following method. The reaction mixture was prepared by mixing $0.25 \mathrm{ml}$ of $2 \mathrm{mM} \mathrm{L}$-arginine$\beta$-naphthylamide (Protein Research Foundation, Japan), $0.5 \mathrm{ml}$ of $0.1 \mathrm{M}$ Tris- $\mathrm{HCl}$ buffer at $\mathrm{pH} 7.0,0.1 \mathrm{ml}$ distilled water with or without inhibitor, into a series of test tubes in a $37^{\circ} \mathrm{C}$ bath. After 3 minutes, $0.15 \mathrm{ml}$ of aminopeptidase B solution which was purified according to the method of Hopsu et al. ${ }^{10)}$ was added and mixed well. Exactly 30 minutes later, $1.0 \mathrm{ml}$ of a solution of the stabilized diazonium salt Garnet GBC $(1 \mathrm{mg} / \mathrm{ml})$ in $1 \mathrm{~m}$ acetic acid buffer at $\mathrm{pH} 4.2$, containing $10 \%$ Tween 20, was added. After standing for 15 minutes at room temperature, absorbancy was read at $525 \mathrm{~nm}$ using a Hitachi-Parkin Elmer Colorimeter. The amount of the enzyme was adjusted to give an optical density of around 0.35 , that is, about $25 \mathrm{nmole}$ of $\beta$ naphthylamine was released. The reaction was also carried out without addition of enzyme solution and the result was taken as blank. The concentration of the inhibitor required for $50 \%$ inhibition $\left(\mathrm{IC}_{50}\right)$ was calculated. We observed that many strains of various species of actinomycetes produce agents active in inhibiting aminopeptidase B, and we isolated an active agent from the strain MD976-C7 which was classified as Streptomyces olivoreticuli.

Bestatin was produced by shaking culture or tank fermentation of the strain MD976-C7 in media containing various carbon sources and nitrogen sources. Glucose, lactose, maltose and starch are examples of carbon sources and $\mathrm{N}-\mathrm{Z}$ amine, yeast extract and soy-bean meal are examples of nitrogen sources suitable for production. A seed culture was prepared by shake-culturing of this strain for 3 days at $27^{\circ} \mathrm{C}$ in a medium containing $2.0 \%$ starch, $2.0 \%$ glucose, $2.0 \%$ soy-bean meal, $0.5 \%$ yeast extract, $0.25 \%$ $\mathrm{NaCl}, 0.32 \% \mathrm{CaCO}_{3}, 0.0005 \% \mathrm{CuSO}_{4} \cdot 5 \mathrm{H}_{2} \mathrm{O}$, $0.0005 \% \mathrm{MnCl}_{2} \cdot 4 \mathrm{H}_{2} \mathrm{O}$, and $0.005 \% \mathrm{ZnSO}_{4}$ $.7 \mathrm{H}_{2} \mathrm{O}(\mathrm{pH}$ 7.4). The typical medium used for production contained $1.5 \%$ maltose, 0.3 $\%$ yeast extract, $1.0 \% \mathrm{~N}-\mathrm{Z}$ amine and 0.3 $\% \mathrm{NaCl}(\mathrm{pH} 7.4)$. Maximum production was attained in $2 \sim 3$ days in the shaking culture and maintained for $2 \sim 6$ days thereafter.

Bestatin was extracted from the culture filtrate by adsorption on activated carbon or Amberlite-XAD resin or by extraction with an organic solvent. For example, it was obtained by the following procedure. Bestatin $(150 \mathrm{mg})$ in 60 liters of a culture filtrate was adsorbed on Amberlite $\mathrm{XAD} \times 4$, and after the column was washed with distilled water, it was eluted with $80 \%$ methanol. The methanol eluate was concentrated under reduced pressure to a syrup and dissolved in 2 liters of distilled water. After the $\mathrm{pH}$ was adjusted to 2.0 , it was extracted with 2 liters of $n$-butanol. The butanol extract was washed with $500 \mathrm{ml}$ of distilled water ( $\mathrm{pH}$ 9.0) and then concentrated under reduced pressure, yielding $30 \mathrm{~g}$ of a crude powder. This was dissolved in 3 liters of $0.2 \mathrm{M}$ pyridine-acetic acid buffer at $\mathrm{pH}$ 3.0. This solution was chromatographed on Dowex $50 \times 8 \quad(100 \sim 200$ mesh) which was equilibrated with the same buffer and eluted by a linear gradient between $0.2 \mathrm{M}$ pyridine-acetic acid at $\mathrm{pH} 3.0$ (1 liter) and $1.0 \mathrm{M}$ pyridine-acetic acid at $\mathrm{pH} 4.75$ (1 liter). As shown in Fig. 1, active fractions 
Fig. 1. Chromatography on Dowex $50 \times 8$ of the crude powder of bestatin.

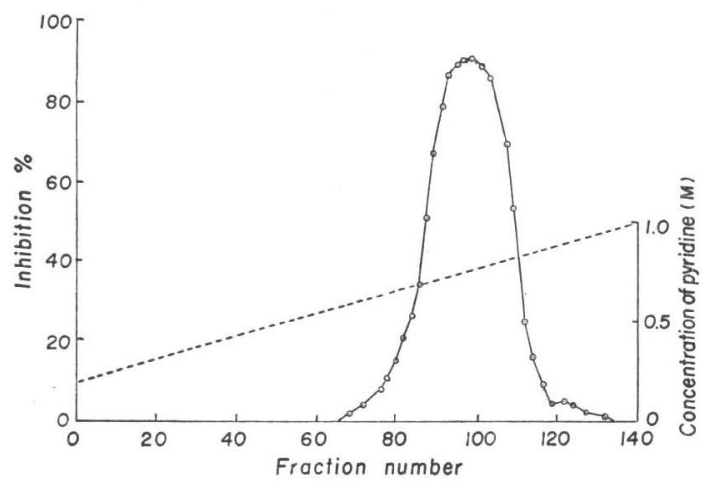

were collected and concentrated under reduced pressure and rechromatographed by the same procedure. Further purification, using butyl acetate- $n$-butanol-acetic acid-water (12: $4: 1: 1)$ on silica gel chromatography, gave the pure compound. The concentration of bestatin required for $\mathrm{IC}_{50}$ was calculated to be $0.05 \mu \mathrm{g} / \mathrm{ml}$.

Bestatin was obtained as colorless needles with the following properties. m.p. 233 $236^{\circ} \mathrm{C} ;[\alpha]_{\mathrm{D}}^{20}-15.5^{\circ}$ (c $1.0,1 \mathrm{~N} \mathrm{HCl}$ ); weak maxima at $248 \mathrm{~nm}, 253 \mathrm{~nm}, 258.5 \mathrm{~nm}, 264.5$ $\mathrm{nm}$ and $268 \mathrm{~nm}$ in methanol solution as shown in Fig. 2. The IR spectrum is shown in Fig.

Fig. 2. Ultraviolet absorption spectrum of bestatin.

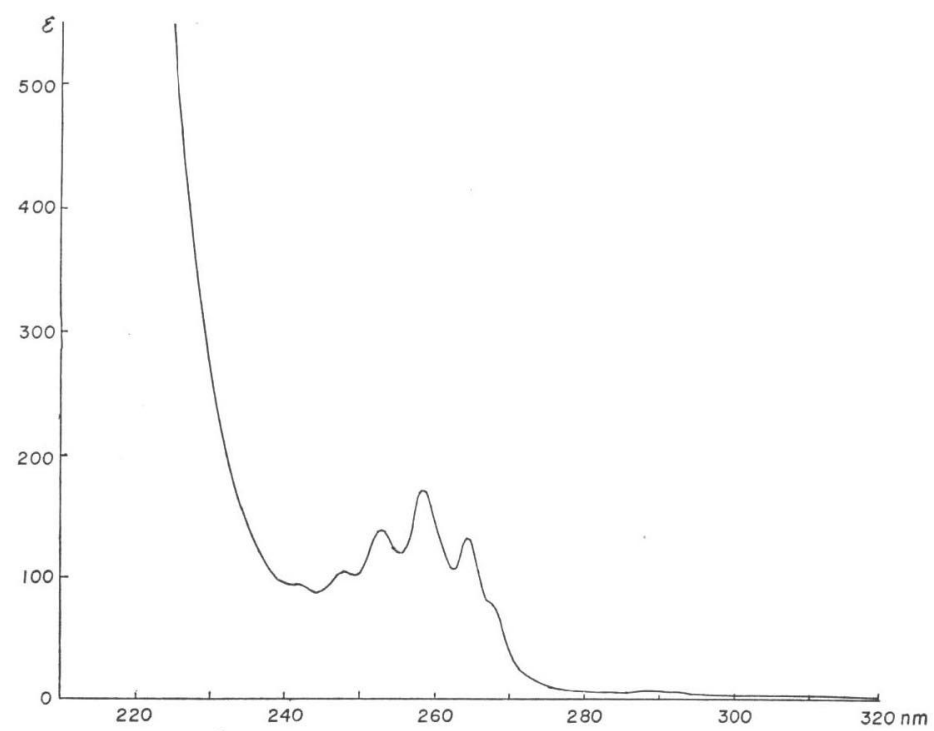

Fig. 3. Infrared absorption spectrum of bestatin ( $\mathrm{KBr})$.

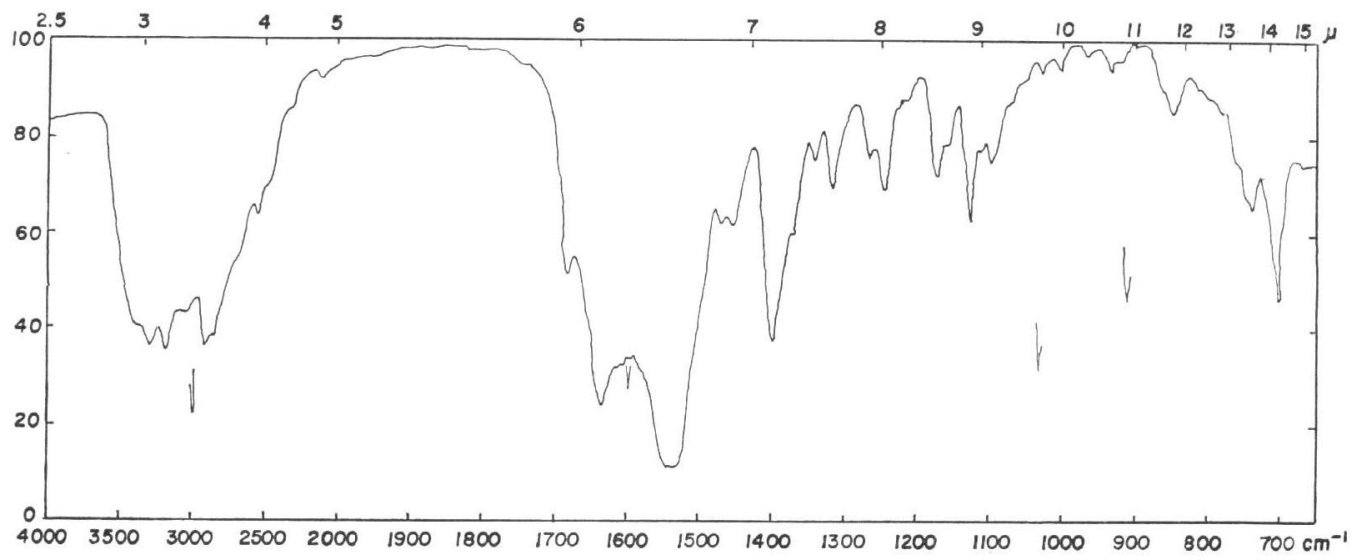


3. The elemental analysis was as follows: Calcd. for $\mathrm{C}_{18} \mathrm{H}_{24} \mathrm{~N}_{2} \mathrm{O}_{4}$ : C 62.32, $\mathrm{H} 7.84, \mathrm{~N}$ 9.08, O 20.75; found: C $61.86, \mathrm{H} 7.79, \mathrm{~N}$ 8.61, O 21.06. Mass spectroscopy of bestatin (the parent peak at 308) and its methylester (the parent peak at 322) supported this formula. It was soluble in acetic acid, dimethylsulfoxide and methanol, less soluble in water, insoluble in ethylacetate, benzene, hexane and chloroform. It gave positive ninhydrin and Rydon-Smith reactions and negative EhrLich and SAKAGUCHI reactions. On thinlayer chromatography on silica gel $G$ (E. Merck), bestatin gave a single spot at $\mathrm{Rf} 0.30$ with butyl acetate-n-butanol-acetic acidwater $(4: 4: 1: 1)$. It moved toward the cathode in formic acid - acetic acid - water $(25: 75: 900)$ under $3,500 \mathrm{~V}$ paper electrophoresis for 15 minutes with an $\mathrm{Rm}$ value of 0.68 taking alanine as 1.0. As will be reported in the next paper, the structure of bestatin was determined to be [(2S, 3R)-3-amino-2-hydroxy4-phenylbutanoyl]-L-leucine.

Bestatin also inhibited leucine aminopeptidase (EC 3.4.11.1). The activity was determined by the following method: to $0.25 \mathrm{ml}$ of $2 \mathrm{~mm}$ L-leucine- $\beta$-naphthylamide (Tokyo Chem. Indust. Co. Ltd., Japan) was added $0.5 \mathrm{ml}$ of $0.1 \mathrm{M}$ Tris- $\mathrm{HCl}$ buffer at $\mathrm{pH} 7.0$ and $0.2 \mathrm{ml}$ of distilled water with or without an inhibitor in a series of test tubes in a $37^{\circ} \mathrm{C}$ bath. After 3 minutes, $0.05 \mathrm{ml}$ of enzyme solution was added and mixed well. Exactly 30 minutes later the reaction was stopped by adding $1.0 \mathrm{ml}$ of Fast Garnet GBC and measured at $525 \mathrm{~nm}$ as described above. The $\mathrm{IC}_{50}$ value of bestatin against leucine aminopeptidase was $0.01 \mu \mathrm{g} / \mathrm{ml}$. Bestatin is competitive with the substrate with a $K i$ value with L-arginine- $\beta$-naphthylamide of $6.0 \times 10^{-8}$ $\mathrm{M}$ and $\mathrm{Ki}$ with L-leucine- $\beta$-naphthylamide of $2.0 \times 10^{-8} \mathrm{M}$. Bestatin is a specific inhibitor of aminopeptidase B and leucine aminopeptidase. It did not show any inhibition of aminopeptidase A, trypsin, chymotrypsin, elastase, papain, pepsin or thermolysin. Bestatin at $100 \mu \mathrm{g} / \mathrm{ml}$ showed no antibacterial and no antifungal activities. It has low toxicity with no death after intraperitoneal injection of $300 \mathrm{mg} / \mathrm{kg}$ to mice.

\author{
Hamao Umezawa \\ TAKAAKI AOYAGI \\ HiROYUKI SUDA \\ MASA HAMADA \\ Tomio TAKeUCHI \\ Institute of Microbial Chemistry \\ 3-chome, Kamiosaki, Shinagawa-ku, \\ Tokyo, Japan
}

(Received August 30, 1975)

\section{References}

1) Umezawa, H.: Enzyme inhibitors of microbial origin. University of Tokyo Press, 1972

2) Aoyagi, T. \& H. Umezawa: Structure and activities of protease inhibitors of microbial origin. "Proteases and Biological Control" (Edited by E. Reich, D. B. Rifkin \& E. Shaw) Cold Spring Habor Conferences on Cell Proliferation. 2: 429 454, 1975

3) Aoyagi, T.; T. Takeuchi, M. Matsuzaki, K. Kawamura, S. Kondo, M. Hamada, K. Maeda \& H. Umezawa: Leupeptins, new protease inhibitors from actinomycetes. J. Antibiotics 22: 283 286, 1969

4) Suda, H.; T. Aoyagi, M. Hamada, T. TAKeUChI \& H. Umezawa: Antipain, a new protease inhibitor isolated from actinomycetes. J. Antibiotics 25: 236 266, 1972

5) Umezawa, H.; T. Aoyagi, H. Morishima, S. Kunimoto, M. Matsuzaki, M. Hamada \& T. TAKEUCHI: Chymostatin, a new chymotrypsin inhibitor produced by actinomycetes. J. Antibiotics 23: 425 427, 1970

6) Umezawa, H.; T. Aoyagi, A. Okura, H. Morishima, T. TAKeuchi \& Y. OKami: Elastatinal, a new elastase inhibitor produced by actinomycetes. J. Antibiotics 26: 787 789, 1973

7) Umezawa, H.; T. Aoyagi, H. Morishima, M. Matsuzaki, M. Hamada \& T. TAKeUchI: Pepstatin, a new pepsin inhibitor produced by actinomycetes. J. Antibiotics 23: 259 262, 1970

8) Suda, H.; T. Aoyagi, T. Takeuchi \& H. UMEZAWA: A thermolysin inhibitor produced by actinomycetes: Phosphoramidon. J. Antibiotics 26: 621 623, 1973

9) Aoyagi, T.; H. Suda, M. Nagai, J. Suzuki \& H. UMEZAwa: Relationship between aminopeptidase activities located on the cellular surface and those on the envelope of myxovirus. Arch. Biochem, Biophys. in press.

10) Hopsu, V. K.; K. K. Mäkinen \& G. G. GlenNer: Purification of a mammalian peptidase selective for $\mathrm{N}$-terminal arginine and lysine residues: Aminopeptidase B. Arch. Biochem. Biophys. 114: 557 566, 1966 